\title{
A role of Spodoptera littoralis nuclear polyhedrosis virus envelope protein pif1 in the process of primary infection of insect midgut
}

\author{
O. Yu. Reviakina, I. M. Kikhno
}

Institute of molecular biology and genetics NAS of Ukraine Academicain Zabolotnog str., 150, Kyiv, 03680 Ukraine

i.m.kikhno@imbg.org.ua

\begin{abstract}
A role of the envelope protein pif1 of Spodoptera littoralis nuclear polyhedrosis virus in the process of viral penetration into the midgut columnar cell of the insect has been investigated. It has been shown that pifl deletion from viral genome does not block viral and cell membrane fusion detected by octadecyl-rhodamin-B-chloride fluorescence dequenching assays. The use of RT PCR techniques allowed demonstrating that pif1 was predicted to be an executor of some step(s) of viral life cycle upstream of viral DNA entry into the nucleus, presumably such as nucleocapsid internalization, nucleocapsid transport, viral DNA release from capsid and its penetration into the nucleus.
\end{abstract}

Keywords: virus entry into the cell, baculovirus, pif1

Introduction. Representatives of different viral groups have common ways of entry into the cell. In particular, enveloped viruses penetrate into the cell by means of viral and cell membranes fusion [1]. This process is maintained by attachment and fusion proteins, which are the components of viral envelope. Although fusion proteins of different viral groups are known to be non-homologous, their structural changes in the process of membrane fusion have common features, which allows supposing the common conservative model of the process. The description of

(C) O. YU. REVIAKINA, I. M. KIKHNO, 2007 this model has been the object of numerous reviews in the recent years [2].

It should be noted that the major part of data on the mechanism of fusion has been obtained while studying small enveloped RNA-containing viruses, specific for the presence of one fusion protein, which is sufficient for maintaining all stages of the process. Large enveloped DNA viruses are different from small RNA viruses in their origin and evolution history [3]. The process of their entry into the cell is barely studied due to its complicated nature, although the involvement of the complex of viral proteins into the membrane fusion allows supposing that there may be disagreement 
between the mechanism of this process and general paradigm.

Baculoviruses, insect pathogens, are not infectious for mammals, which makes them a convenient model to study the process of penetration of large DNA viruses into the cell. Baculoviruses are specific for longer evolutionary history, compared to vertebrate viruses, and thus, the process of their penetration into the cell is of great interest due to its archaic character. Besides, some specific features of baculoviruses allow expecting special ways of entry into the cell. One of the unique features of baculoviruses is the existence of two forms of virus particles, formed at different stages of life cycle and different in origin, membrane contents, tropism to different cells, and ways of entry into the cell.

Budded virus (BV) particles are formed at the early stages of virus life cycle. BV penetrates into the cell via endocytosis [4]. Envelope protein gp64, which provides attachment and fusion of BV with endosomal membrane, is specific for features of standard fusion protein. The process, maintained by this protein, has common features with that of other viruses [5], which supposes its correspondence to the common model. BV particles are responsible for systemic infection of all organs and tissues of the insect.

Polyhedra derived virus (PDV) particles are formed at the final stages of infection. The name PDV indicates the inclusion of the particles into the protein capsule called polyhedra. PDV nucleocapsids are responsible for primary infection of midgut columnar cells. They penetrate into the cytoplasm via direct fusion of viral envelopes and membranes of columnar cell microvilli [6]. Neither the mechanism of the process is known, nor PDV fusion protein is identified. PDV of Autographa californica (Ac) nuclear polyhedrosis virus (NPV), the most studied representative of baculoviruses, includes circa 44 proteins, encoded by the virus [7]. At least 4 of them were shown to be absolutely required in the process of nucleocapsid entry into the cell -3 per os infectivity factors - pif1 [8], pif2 [9], pif3 [10], and p74 [11]. Deletion of genes of the mentioned proteins results in the loss of PDV infectivity. Genes of these proteins are present in genomes of all (over 30) sequenced baculoviruses, which presupposes the conservative mechanism of PDV penetration into the cell. pif3 was determined not to participate in the processes of attachment and fusion, its role remains unclear, whereas pif1, pif2, p74 promote attachment $[10,12]$. Authors of the mentioned works showed that attachment efficiency of these genes deletion mutants is 3-fold lower than that of wild type virus. At the same time the attached virus tends to fusion with microvillar membranes, which is detected by the octadecyl-rhodamine-B-chloride (R18) fluorescence dequenching assay, which in author's opinion allows excluding the possibility of direct involvement of these proteins into the fusion process. It is yet to be discovered why attachment and fusion of $1 / 3$ of viral particles does not result in productive infection.

Current work is dedicated to further functional investigation of one of the factors of Spodoptera littoralis (Spli) PDV infectivity, namely pif1. Fusion capacity of pif 1 deletion mutant has been investigated in in vitro experiments. The application of PCR method attempted to answer the question - which of the stages of viral cycle is blocked by the absence of this gene product?

Materials and Methods. Viruses and larvae. Wild-type Spli NPV strain M2 and earlier obtained on its basis plaque isolate Spli $\Delta 4$ with deletion of pif1 were used [8]. Spli larvae of different age, grown and artificially fed in insectarium were used for experiments. Larvae were infected by feeding them with polyhedra suspension or purified PDV in $10 \%$ sucrose.

Purification of polyhedra and PDV particles. Polyhedra and PDV particles were purified according to the procedure, described by Braunagel et al. [13]. $40 \mathrm{~g}$ of dead larvae were homogenised in $100 \mathrm{ml}$ of $0.1 \%$ SDS solution, homogenate was filtered several times through the cotton tissue. Polyhedra were precipitated by centrifugation at $6000 \mathrm{rpm}$ for $10 \mathrm{~min}$. Pellet was resuspended in $0.15 \mathrm{M} \mathrm{NaCl}$ solution and centrifuged once more at the same conditions. Pellet was resuspended in water and then layered onto 50-60\% sucrose-TE gradient. After 1-hour centrifugation at $25000 \mathrm{rpm}$, polyhedra, located on interphase, were collected. The suspension was diluted several times with water and polyhedra were pelleted at $10000 \mathrm{rpm}$ for $20 \mathrm{~min}$. Obtained pellet was resuspended in water to final concentration of $5 \cdot 10^{9}$ polyhedra per $1 \mathrm{ml}$. 
PDV were released from polyhedra by alkaline treatment. $900 \mu \mathrm{l}$ of suspension were mixed with 300 $\mu \mathrm{l}$ of $0.2 \mathrm{M} \mathrm{Na}_{2} \mathrm{CO}_{3}$ and incubated for $15 \mathrm{~min}$ at room temperature. Suspension was neutralised with $0.1 \mathrm{M}$ of tris- $\mathrm{HCl}, \mathrm{pH}$ 7.4. Insoluble polyhedra were eliminated by centrifugation at $5000 \mathrm{rpm}$ for 5 min performed in Eppendorf centrifuge. Supernatant was layered onto $20-60 \%$ sucrose-TE gradient. After 1 hour centrifugation at $90000 \mathrm{~g}$ a band, containing PDV particles, at the interphase was removed. PDV suspension was diluted 3-4 times with water and viral particles were pelleted at $90000 \mathrm{~g}$ for $30 \mathrm{~min}$. The pellet was carefully resuspended in cold PBS buffer (137 $\mathrm{mM} \mathrm{NaCl}, 2.7 \mathrm{mM} \mathrm{KCl}, 10 \mathrm{mM} \mathrm{Na} \mathrm{HPO}_{4}, 1 \mathrm{mM}$ $\mathrm{KH}_{2} \mathrm{O}_{4}, \mathrm{pH}$ 7.4).

PDV quantity was calculated using Volkman criteria [14], which states that $1 \mu \mathrm{g}$ of viral proteins corresponds to $1.8 \cdot 10^{9} \mathrm{PDV}$. PDV proteins concentration was determined using BSA assay kit (Pierse, USA) according to the manufacturer's instruction.

Fluorescent labelling of PDV particles. Fluorescent label R18 was introduced into membrane according to the method described in [15]. $7 \mu$ of R18 ethanol solution $(1 \mu \mathrm{g} / \mathrm{ml})$ were added to $500 \mu \mathrm{l}$ of PDV suspension, containing $1 \mathrm{mg} / \mathrm{ml}$ of viral proteins. The sample was incubated in dark room at room temperature for 1 hour, diluted 3 times with PBS buffer and pelleted in Eppendorf centrifuge at the maximal speed for $30 \mathrm{~min}$ at $4^{\circ} \mathrm{C}$. PDV were washed twice in three volumes of PBS, pellet of labelled PDV was suspended in $500 \mu \mathrm{l}$ of PBS.

Membrane vesicle isolation from insect midgut cells. Midguts of 7-day-old larvae were isolated using microsurgical tools and magnifying glass, and then treated according to the method, described in [16]. $500 \mathrm{mg}$ of midgut tissue preparation were homogenised on ice in $200 \mu \mathrm{l}$ of buffer A (300 mM mannitol, 5 mM EDTA, $17 \mathrm{mM}$ tris-HCl, $\mathrm{pH}$ 7.5) with addition of protease inhibitor cocktail (Promega, USA) in Eppendorf vial using pestle and then needles of different diameter (23-26 G). Then $4.5 \mathrm{ml}$ of buffer A with protease inhibitors and $4.5 \mathrm{ml}$ of $24 \mathrm{mM} \mathrm{MgCl}_{2}$ were added with subsequent incubation of homogenate on ice for $15 \mathrm{~min}$. Homogenate was centrifuged at 5000 rpm for $15 \mathrm{~min}$ at $4^{\circ} \mathrm{C}$. Supernatant was removed and centrifuged at $19000 \mathrm{rpm}$ for $30 \mathrm{~min}$ at $4^{\circ} \mathrm{C}$. The pel- let was resuspended in the same volume of buffer A and $\mathrm{MgCl}_{2}$ and then the procedure of high-speed centrifugation was repeated. Obtained pellet of membrane vesicles was resuspended in small volume of PBS buffer.

Monitoring of membrane fusion. Fusion of viral and cell membranes was registered as earlier described for Ac NPV [17], according to the method, based on fluorescence dequenching assay of R18, incorporated into viral membrane in the concentration leading to "self-quenching" of fluorescence [18]. $10 \mu \mathrm{l}$ of membrane vesicle suspension $(1 \mathrm{mg} / \mathrm{ml})$ were mixed with different amounts of M2 or $\triangle 4 \mathrm{PDV}$ (from $1 \cdot 10^{9}$ to $1 \cdot 10^{10}$ ), sample volumes were adjusted to $200 \mu \mathrm{l}$ by PBS buffer. The samples were incubated in dark room at $27^{\circ} \mathrm{C}$ for 4 hours, with periodic shaking. Then each sample volume was adjusted to $1 \mathrm{ml}$ by PBS buffer and intensity of fluorescence was measured using Cary eclipse spectrofluorimeter (Varian, USA), excitation wavelength $560 \mathrm{~nm}$ and emission wavelength $590 \mathrm{~nm}$. Intensity of fluorescence for each sample was measured one more time after addition of triton X-100 to final concentration of $1 \%$. Fluorescence dequenching percentage was calculated using standard formula:

$$
\text { dequenching } \%=100 \cdot\left(F_{\mathrm{s}}-F_{0}\right) /\left(F_{\mathrm{t}}-F_{0}\right) \text {, }
$$

where $F_{\mathrm{s}}$ - fluorescence intensity of sample; $F_{0}$ fluorescence intensity of labeled PDV; $F_{\mathrm{t}}$ - fluorescence intensity of sample after addition of triton X-100.

Isolation of RNA from midgut cells. Midgut tissue cells, isolated from infected larvae, were used as the source RNA. RNAs were isolated using RNA easy Protect mini kit (Qiagen, USA) according to the manufacturer's instruction.

Amplification of egt gene region using RT-PCR. RNA preparations, isolated from midguts of infected larvae, were used to obtain cDNA gene copies using reverse transcriptase. The following primers, homologous to N-terminal region of Spli NPV egt gene, were used in PCR: direct - TCACAGTCTGGTGGT and reverse -CGCTGAGACCTTTGA. Reactions of reverse transcription and amplification were carried out using One Step RT-PCR kit (Qiagen) in accordance to the manufacturer's instructions. 


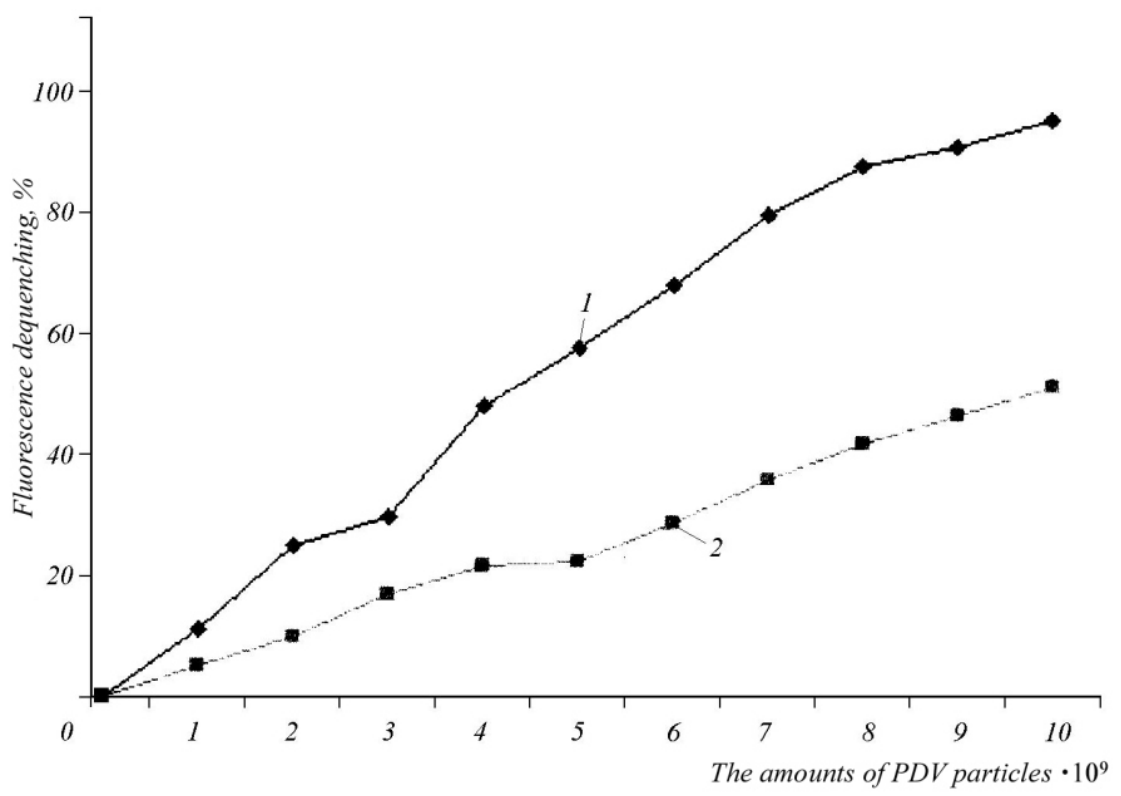

Fig.1 Dependence of fluorescence dequenching percentage on the amounts of PDV particles: $1-\mathrm{M} 2$ PDV; $2-\Delta 4$ PDV. Increasing number of labeled R18 PDV M2 or PDV $\Delta 4$ was mixed with 10 $\mu \mathrm{g}$ of membrane vesicles and incu $\beta \alpha \tau \varepsilon \delta$

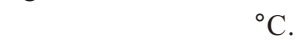

Results and Discussion. Investigation of fusion kinetics of Spli M2 and $\triangle 4 P D V$ with membranes of midgut columnar cells. Fluorescence dequenching assay of R18 is widely used in studying of membrane fusion. This assay is based on the fact that incorporation of fluorochrome molecules R18 into membrane lipid bilayer in certain concentration results in the effect of fluorescence "self-quenching", caused by the interaction of neighbouring molecules. The fusion of labelled and non-labelled membranes leads to redistribution of R18 between donor and recipient membranes, which results in "dilution" of the label, decrease in its concentration and, consequently, in fluorescence intensity decrease.

Fluorescence dequenching, registered by spectrofluorimeter, was used to study the fusion kinetics of labelled PDV particles with membrane vesicles, isolated from insect midgut cells.

Different amounts of R18-labelled viral particles were incubated in the mixture with $10 \mu \mathrm{g}$ of membrane vesicles for 4 hours at $27^{\circ} \mathrm{C}$. The increase in PDV M2 amount from $1 \cdot 10^{9}$ to $8 \cdot 10^{9}$ was accompanied by proportional increase in membrane fusion percentage, detected as increase in fluorescence dequenching from 11 to $88 \%$ respectively (Figure 1). Further increase in PDV amount to $1 \cdot 10^{10}$ results in insignificant plateau increase of fluorescence dequenching to $95 \%$, which evidences to saturation. Similar tendency to increase in fluorescence dequenching due to the increase in viral particle amount has been observed for PDV $\Delta 4$ as well, which confirms the fact of membrane fusion of deletion mutant envelope with membrane vesicles. At the same time it took almost 2.5 times more viral particles, comparing to wild type virus, to achieve the same level of fluorescence dequenching. As it has been mentioned above, investigation of pif1 on models of Spli NPV and Ac NPV revealed phenotypic manifestation of these genes to be equal in both viruses, i.e. their deletion results in the loss of infection capability by PDV $[8,10]$.

Current paper reveals that deletion of this gene does not impede the fusion of Spli NVP and cell membrane, which is in good correlation with the data on $A c$ NVP [10]. The authors of the latter work showed that fluorescence dequenching percentage during fusion of deletion mutant $A c$ NVP with cell membranes is reduced three times, compared to wild type virus. This fact is explained by three time decrease in number of mutant viral particles, attached to the microvilli. We have not studied efficiency of attachment of Spli to membranes, as it has been performed for $A c$ NVP, yet it is possible to suppose that fusion efficiency of $\Delta 4$ PDV, which is 2.4 times lower compared to M2, can be considered as the result of decreased efficiency of this virus attachment. Therefore, Spli NVP piflcan be considered as functional analogue of pif1 $A c$ NVP, 
namely attachment factor. It is also evidenced indirectly by absolute conservatism of four PDV entry proteins, which presupposes singular mechanism of penetration, as the common mechanism requires functional conservatism of its performers.

Investigation of PDV DNA presence in the nuclei of infected midgut cells. As deletion mutants, not so efficiently, yet were attached and fused with the cell membranes, while infection was blocked, it can be supposed that, along with the function of attachment, pif1 participates in the initiation of other processes of viral life cycle. It is supposed theoretically that the function of pif1 is the maintenance of some stages of infection, following the fusion of membranes, namely, penetration of nucleocapsid into cytoplasm of microvillus, transport to the nucleus, overcoming of viral DNA barrier of nuclear membrane, DNA replication, transcription and translation of viral genes, formation of nucleocapsid, and withdrawal of nucleocapsids from the cell. Participation of pif1 in the following events is unlikely, as BV particles with deleted pif1, injected into the insect haemolimph, result in normal infection process [8].

The facts that promoters of early baculoviral genes are recognized by enzymatic systems of host cells and that transcription of these genes is performed by host DNA-polymerase are commonly known. Early promoters function after transfection in the insect cell and do not require any products of viral genes for maintaining their activity $[19,20]$. On the basis of the abovementioned data on specificities of early baculoviral promoters, we put forward the supposition that the absence of transcripts of early baculoviral gene in the nucleus of midgut cells may testify to the absence of viral DNA in the nucleus.

To verify the presence of viral DNA in the nucleus of infected cell we carried out the following experiment: 6-day-old Spli NPV larvae were infected by feeding with high concentrated suspension of Spli NPV M2 or $\Delta 4$ polyhedra $\left(3 \cdot 10^{9}\right.$ polyhedra in $\left.1 \mathrm{ml}\right)$. In 7 hours after infection, insects were decapitated, midguts were removed and released from their contents. Total RNA was isolated from midguts. cDNA pool of matrix RNA has been obtained using reverse transcriptase on the basis of these samples. Reaction of amplification using the primers, homologous to
$\mathrm{N}$-terminal region of early egt gene, was used as the evidence of presence/absence of cDNA gene copy in the investigated samples. Positive result was registered during reaction of amplification using cDNA samples of insects, infected with M2 (Figure 2). Reiterated PCR using $\triangle 4$-infected insects cDNAs revealed the absence of egt RNA in them. The results obtained reveal that DNA virus with deleted pifl gene does not reach the nucleus. Thus, it is possible to conclude that function of pif1 is to maintain the stages of infection, preceding the viral DNA entry into the nucleus, supposedly nucleocapsid nto cytoplasm of microvillus, transport to the nucleus or viral DNA penetration into the nucleus.

As pif1 is known to belong to envelope proteins, and not a nucleocapsid component, it is hard to suppose its direct participation in transport or release of DNA. In this case it can be supposed that pif1, attached to specific receptors, is capable of switching cell signaling pathways, providing the execution of given functions [10]. This hypothesis is supported by Okhawa et al., who point out the fact that amino acid sequence of $A c$ NVP pifl contains RGD-motif, specific to protein-ligands of integrins (as integrins are the transductors of extracellular signals). Not disputing with the possibility of signal transduction in the cell via pif1, we would like to pay special attention to the presence of motif in amino acid sequence as necessary but insufficient factor to judge about the functionality of this motif. Additional confirmation to functional significance of the motif is its conservation in protein homologues. At the moment, there are pif1 aminoacid sequences of over 30 baculoviruses, available in the Gene Bank database. Their analysis revealed the absence of conservative RGD-motif. Amino acid sequence of Spli NVP pif1does not contain this motif at all, which casts doubts on its functional significance in Ac NVP as well. Continuing the discussion with Okhawa et al. we would like to underline the inability of crossing out of fusion function from the list of possible pifl functions. We found it possible to suppose that pif1 may be direct performer of the membrane fusion process. Modern fusion paradigm, applicable for both artificial lipid bilayers and protein-containing biological membranes, suggests the presence of several stages of this process [21]. 


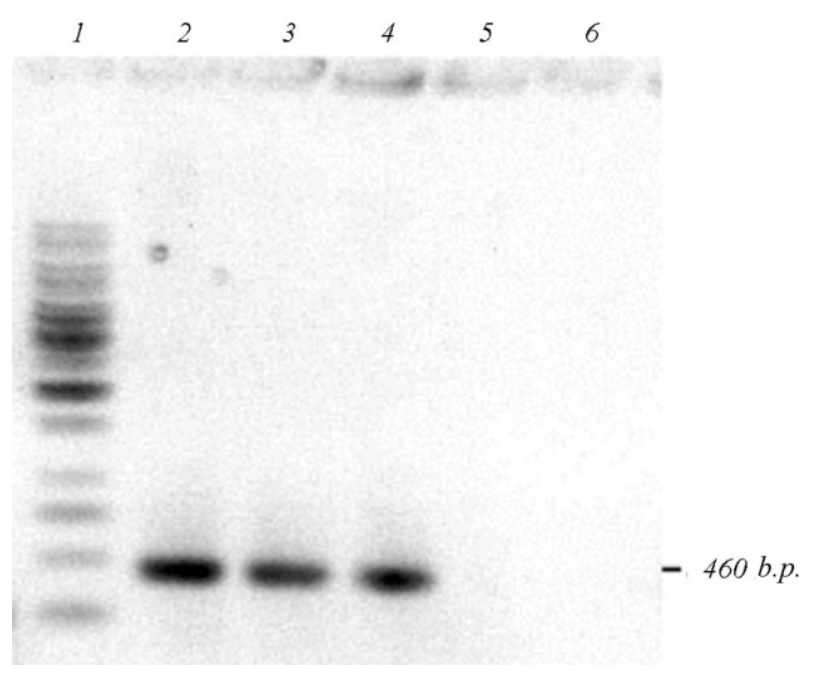

Fig.2 Electrophoretic analysis of products of amplification of cDNA copies of RNA, isolated from midguts of infected larvae: 1 marker $1 \mathrm{~kb}$ (Fermentas); 2 - positive control (amplification of purified DNA Spli M2); 3, 4-insects, infected with PDV M2; 5, 6-insects, infected with PDV 4 .

One of the important stages of the process is the state of semi-fusion, which is characterized by mixing of external layers of recipient and target membranes, whereas internal layers remain intact. The subsequent state of internal layers mixing results in complete fusion, fusion pore formation and mixing of water contents of two compartments, up to that moment separated by membranes. It is also important that fluorescence dequenching of R18 allows detecting distribution of fluorochrome between lipids of donor and recipient membranes, at the same time it is impossible to determine whether complete or incomplete membrane fusion reflects this process. To differentiate these stages, distribution analysis of their water-soluble components is used along with study on distribution of liposoluble components [22]. In the frames of current model of fusion the presence of one fusion protein is sufficient for maintaining of all stages of process, thus, pif1 can not be considered as a candidate for the role of fusion protein. However, the latest data, obtained in the investigation of herpes viruses, allow supposing that the mechanics of fusion in complex DNA-containing viruses may be different from the described one.
In herpes viruses fusion is provided by the complex of four conservative proteins, namely $\mathrm{gD}, \mathrm{gH}$, $\mathrm{gL}$, and $\mathrm{gB}$, acting consecutively, i.e. $\mathrm{gD}$ is attachment protein, gHL complex provides semi-fusion, and $\mathrm{gB}$ completes the process of fusion, which results in the pore formation [23]. Similarly to herpes viruses it is possible to suppose that incomplete fusion may be the obstacle for the penetration of nucleocapsid into the cell, and pif1 is the performer, or one of the performers, of the process of complete fusion. It is worth mentioning that though fusion of herpes viruses is performed by a harder scheme, general features of proteins of the complex are the same as for all fusion proteins. One of these features is the presence of glycosylation. Unlike all other known fusion proteins, pif1 is non-glycosylated [8], which casts doubts on its function as fusion protein. However, there are evidences that glycoproteins are not involved into the process of PDV fusion.

The treatment of infected cells with tunicamycine usually results in the absence or significant decrease in infectivity of virus, obtained from these cells, as tunicamycine interferes with the process of glycosylation of fusion proteins. Whereas it is justified for BV [24], treatment with tunicamycine does not influence infectivity of PDV [25]. Moreover, some details of PDV fusion process are different from those of other viruses. For all investigated viruses direct fusion of viral and cell membranes is $\mathrm{pH}$-independent. Efficiency of PDV fusion increases with increasing $\mathrm{pH}$ value, reaching its maximum at $\mathrm{pH}$ 9-11 [17]. For all known viruses the decrease of temperature to $4^{\circ} \mathrm{C}$ is commonly accepted method of fusion blocking, yet such a temperature is permissive for PDV fusion with microvillus membranes [17].

The abovementioned facts evidence to the fact that the study on PDV penetration into the cell will allow discovering the unknown mechanisms of this process, maintained by the complex of new type of fusion protein(s).

Further investigation on process of PDV infection by electron microscopy as well as monitoring of degree of membrane fusion using water-soluble dyes will enable to either confirm or reject the hypothesis on pif1 belonging to new type of fusion proteins. 


\section{О. Ю. Ревякина, И. М. Кихно}

Роль белка pif1 оболочки вируса ядерного полиэдроза Spodoptera littoralis в процессе проникновения вируса в клетку

\section{Резюме}

Исследовали роль pif1 - белка оболочки вируса ядерного полиэдроза S. littoralis в процессе проникновения вируса в колончатую клетку кишечника насекомого. Показано, что делетирование pifl из вирусного генома не блокирует проиесс слияния вирусной и клеточной мембран, детектируемого методом восстановления флуоресченции октадеиил-родамин-В-хлорида. $C$ привлечением техники ОТ-ПЦР показано, что функцией рif1 является обслуживание одного или нескольких этапов жизненного иикла вируса, предшествующих проникновению вирусной ДНК в ядро, предположительно таких, как интернализация нуклеокапсида, его транспортировка, освобождение вирусной ДНК из капсида и ее внедрение в ядро.

Ключевые слова: проникновение вируса в клетку, бакуловирус, pif1.

\section{REFERENCES}

1. Hernandez L. D., Hoffman L. R., Wolfsberg T. G., White J. M. Virus-cell and cell-cell fusion // Ann. Rev. Cell Develop. Biol.-1996.-12.-P. 627-661.

2. Earp L. J., Delos S. E., Park H. E., White J. M. The many mechanisms of viral membrane fusion proteins // Curr. Top. Microbiol. and Immunol.-2005.-285.-P. 25-66.

3. Shackelton L. A., Holmes E. The evolution of large DNA viruses: combining genomic information of viruses and their hosts // TRENDS Microbiol.-2004.-12.-P. 458-465.

4. Blissard G. W., Wenz J. R. Baculovirus gp64 envelope glycoprotein is sufficient to mediate $\mathrm{pH}$-dependent membrane fusion // J. Virol.-1992.-66.-P. 6829-6835.

5. Marcovic I., Pulyaeva H., Sokoloff A., Chernomordic L. V. Membrane fusion mediated by baculovirus gp64 involves assembly of stable gp64 trimers into multiprotein aggregates // J. Cell Biol.-1998.-143.-P.1155-1156.

6. Granados R. R., Lawler K. A. In vivo pathway of Autographa californica baculovirus invasion and infection // Virology.-1981.-108.- P. 297-308.

7. Braunagel S. C., Russell W. K., Rosas-Acosta G., Russell D. H., Summers M. D. Determination of the protein composition of the occlusion-derived virus of Autographa californica nucleopolyhedrovirus // Proc. Nat. Acad. Sci. USA.-2003.100.-P. 9797-9802.

8. Kikhno I., Gutierrez S., Croizier L., Croizier G., Ferber L. M. Characterization of pif, a gene required for per os infectivity of Spodoptera littoralis nucleopolyhedrovirus // J. Gen. Virol.-2002.- 83.-P. 3013-3022.
9. Pijlman G. P., Pruijssers A. J. P., VlakJ. M. Identification of pif-2, a third conserved baculovirus gene required for per os infection of insects // J. Gen. Virol.-2003.-84.-P. 20412049.

10. Ohkawa T., Washburn J. O., Sitapara R., Sid E., Volkman L. E. Specific binding of Autographa californica $M$ nucleopolyhedrovirus occlusion-derived virus to midgut cells of Heliothis virescens larvae is mediated by products of pif genes Ac119 and Ac022 but not by Ac115// J. Virol.2005.-79.-P. 15258-15264.

11. Kuzio J., Jacques R., Faulkner P. Identification of p74, a gene essential for virulence of baculovirus occlusion bodies // Virology.-1989.-173.- P. 759-763.

12. Haas-Stapleton E. J., Washburn J. O., Volkman L. E. P74 mediated specific binding of Autographa californica M nucleopolyhedrovirus occlusion-derived virus to primary cellular targets in the midgut epithelia of Heliothis virescens larvae // J. Virol.-2004.-78.-P. 6786-6791.

13. Braunagel S. C., Summers M. D. Autographa californica nuclear polyhedrosis virus, PDV, and ECV viral envelopes and nucleocapsids: structural proteins, antigens, lipid and fatty acid profiles // Virology.-1994.-202.-P. 315-328.

14. Volkman L. E., Summers M. D., Hsieh C. H. Occluded and nonoccluded nuclear polyhedrosis virus grown in Trichoplusia ni: comparative neutralization comparative infectivity, and in vitro growth studies // J. Virol.1976.-1.-P. 820-832.

15. Boyyad A., Menezes $J$. Comparative study of herpes simplex virus receptor expression on human lymphoid cells // Virology.-1990.-179.-P. 905-910.

16. Wolfersberger M., Luethy P., Parenti P., Sacci F. V., Giordana B., Hanoret G. M. Preparation and partial characterization of amino acid transporting brush border membrane vesicles from the larvae midgut of the cabbage butterfly (Pieris brassicae) // Comp. Biochem. and Physiol.-1987.-86.- P. 301-308.

17. Horton H. M., Burand J. P. Saturable attachment sites for polyhedron-derived baculovirus of insect cells and evidence for entry via direct membrane fusion // J. Virol.-1993.67.-P. 1860-1868.

18. Srinivasakumar N., Ogra $P . \quad$ L., Flanagan $T . \quad D$. Characteristics of fusion of respiratory syncytial virus with HEp-2 cells as measured by R18 fluorescence dequenching assay // J. Virol.-1991.-65.-P. 4063-4069.

19. O'Reilly D. R., Miller L. K. Regulation of expression of a baculovirus ecdysteroid UDP glucosyltransferase gene // J. Virol.-1990.-64.-P. 1321-1328.

20. Kogan P. H., Blissard G. W. A baculovirus gp64 early promoter is activated by host transcription factor binding to CACGTG and GATA elements // J. Virol.-1994.-68.P. 813-822.

21.Chernomordic L. V., Zimmerberg J., Kozlov M. M. Membranes of the world unite! // J. Cell Biol.-2006.-175.P. 201-207.

22. Melikyan G. B., White J. M., Cohen F. GPI-anchored influenza hemagglutinin induced hemifusion of both red blood cell and planar bilayer membranes // J. Cell Biol.1995.-131.-P. 679-691.

23. Subramanian R. P., Geraghty R. J. Herpes simplex virus type 1 mediates fusion through a hemifusion intermediates by sequential activity of glycoprotein D, H, L, and B // Proc. Nat. Acad. Sci. USA.-2007.-104.-P. 2903-2908.

24. Charlton C. A., Volkman L. E. Effect of tunicamycin on the structural proteins and infectivity of budded Autographa 
californica nuclear polyhedrosis virus // Virology.- 1986.154.-P. 214-218.

25. Kelly D. C., Lescott T. Baculovirus replication: glycosylation of polypeptides synthesized in Trichoplusia ni nuclear polyhedrosis virus-infected cells and the effect of tunicamycin // J. Gen. Virol.-1983.- 64.-P. 1915-1926.

UDC 578.841:578.23.3

Recieved 06.04.07 